of muddy sand, below 70 feet of surface and Bonlder-clay, in sinking a pit $2 \frac{1}{2}$ miles west, or down the valley, from the above quarry. The tusk was broken up and destroyed, the workmen mistaking it for wood; a fragment was procured and lodged in the Hunterian Museum, Glasgow, for preservation. The shells were identified by Mr. John Young, F.G.S., of this museum. as follows :-Astarte compressa, Cyprina Islandica, Fusus? a fragment, Mya truncata, Nucula tenuis, Tellina balthica, Natica Gronlandica, Turritella terebra. Some of these, and other fragments of shells found, had a waterworn appearance. The section taken downwards is as follows :surface and Boulder-clay 78 feet, muddy sand, the mud and sand finely laminated in alternate layers, about two feet, soft sand one foot, gravelly sand (fossiliferous) 20 feet, resting on the Carboniferous strata. This section is interesting, by throwing light upon the position, and age, of these fossiliferous beds, as well as evidence of their extent. Dr. Bryce makes them Pre-Glacial, and of the age of the Upper Crag (Quarterly Journal, vol. xxi. p. 213). From an examination of the rock specimens in the 20 feet bed of sand underlying the fossiliferous beds, they are largely made up of erratics, highland schists, gneiss, granite, Old Red Sandstone, quartz, etc. These erratics are greatly in excess in this bed of sand, to what they are in the Boulder-clay of the district, that overlies the fossiliferous beds. At one time I made a minute examination of the rocks in the Boulder-clay of this district, and found the erratics small, about 4 per cent. ; but in this bed they are nearly 30 per cent. of the whole rock contents. This is certainly against the Pre-Glacial age of the beds.

R. Craig.

Langside, Beith.

\title{
THE DISTURBANCES AT VOBSTER IN SOMERSET.
}

SIR,-The announcement of the discovery of Millstone Grit at Vobster, made in your last Number by the Rev. H. H. Winwood, is so interesting that I hope he will give further particulars, and publish a section of the facts observed. In my diagram-section (Geol. Mag. Vol. VIII. p. 153) I have inserted the Millstone Grit at Upper Vobster, but not at Lower Vobster (to which Mr. Winwood, I presume, refers) : its presence at this latter place will simplify the explanations, and dispose of one argument against the "overthrow theory." To that theory, which supposes that the Limestone masses of Vobster were portions of rocks "squeezed together, thrown up, and finally folded over from the main ridge" (i.e. the Downhead Anticlinal), my chief objection is that I can discern no evidence in the structure or lie of the Lower Carboniferous rocks and Old Red Sandstone to favour the notion. Why not take into account the ascertained structure in these hard and well-marked rocks, and not rely simply on the evidence in the neighbourhood of Vobster, where in the comparatively soft and yielding Coal-measures (to quote the words of Mr. McMurtrie) "we find an amount of confusion and distortion which literally baffles description"?

We have actual evidence of a faulted-anticlinal at Penhill House, 
west of Binegar, the continuation of which disturbance may, and very probably does, run through the Vobster coal-district, to the north of the Downhead anticlinal: and it would be quite capable of producing the phenomena of the inverted Limestone-masses (see GEoL. MaG. Decade II. Vol. III. p. 457).

My belief is, that had a diagram on a true scale (as regards the configuration of the land and the great divisions of the rocks), been attempted by those who now support the "overthrow theory," this theory would never have found an advocate. Will Mr. Winwood kindly furnish such a diagram? HORACE B. WOODWARD.

FAKENHAM.

\section{THE GEOLOGY OF ANGLESEA.}

SIR,-I do nut clearly see the object of the paper by Dr. R. D. Roberts, which appears in the May Number (p. 152). It is simply a recapitulation, from his point of view, of the arguments which have already been submitted by us to your readers, with whom the matter, so far as I am concerned, must now rest. It is, perhaps, rather singular that Dr. Roberts should strive so persistently to hupt to the death an argument which was adduced by me in support of a conclusion which he himself accepts, viz. the Archæan age of the granitoid series. I must decline to adopt his views as to the mode in which I shall use my private note-book. I claim to be the best judge of what is essential or non-essential to my argument. The faulted sections have not been published, simply because they are not required. Dr. Roberts evades the difficulties which I pointed out in his reasoning on the sections at Bryngwallen and Penlon, on the pretext that he has discussed them in his dispute with Prof. Bonney. This is quite erroneous, as those who have followed the controversy can judge.

From Dr. Roberts's paper, your readers will have learned, probably not without surprise, that he sent to you his list of my "errors" at a time when he had not access to my papers, and they will know how to estimate the accuracy of a critic who can make sweeping charges against another, without taking the trouble to ascertain if he is truly representing his opponent's views. Dr. Roberts has, however, candidly apologized for one of his random assertions; and the other corrections will, I doubt not, appear in his next communication.

Wellivgton, Salop.

C. Calraway.

THE HEADON HILL SECTION.

Sir,-Possibly Prof. Judd's letter in the April Number may have been read by some who had not seen mine. I therefore ask you to reprint the portions to which he refers. I wrote :-

"When we recollect that one of the authors (of the paper under discussion) was born in the Isle of Wight, and spent the best years of his life in professional work, chiefly in exploring and collecting from the Eocene beds of the district, some little amount of warmth 